\title{
Removal of EpCAM-positive tumor cells from blood collected during major oncological surgery using the Catuvab device- a pilot study
}

\author{
Andreas Winter ${ }^{1 *}$, Kai Zacharowski ${ }^{1}$, Patrick Meybohm ${ }^{1,2}$, Andreas Schnitzbauer ${ }^{3}$, Peter Ruf ${ }^{4}$, \\ Claudia Kellermann ${ }^{4}$ and Horst Lindhofer ${ }^{4}$
}

\begin{abstract}
Background: Intraoperative blood salvage (IBS) is regarded as an alternative to allogeneic blood transfusion excluding the risks associated with allogeneic blood. Currently, IBS is generally avoided in tumor surgeries due to concern for potential metastasis caused by residual tumor cells in the erythrocyte concentrate.

Methods: The feasibility, efficacy and safety aspects of the new developed Catuvab procedure using the bispecific trifunctional antibody Catumaxomab was investigated in an ex-vivo pilot study in order to remove residual EpCAM positive tumor cells from the autologous erythrocyte concentrates (EC) from various cancer patients, generated by a IBS device.

Results: Tumor cells in intraoperative blood were detected in 10 of 16 patient samples in the range of $69-2.6 \times 10^{5}$ but no residual malignant cells in the final erythrocyte concentrates after Catuvab procedure. IL-6 and IL-8 as proinflammatory cytokines released during surgery, were lowered in mean 28-fold and 52-fold during the Catuvab procedure, respectively, whereas Catumaxomab antibody was detected in 8 of 16 of the final EC products at a considerable decreased and uncritical residual amount (37 ng in mean).

Conclusion: The preliminary study results indicate efficacy and feasibility of the new medical device Catuvab allowing potentially the reinfusion of autologous erythrocyte concentrates (EC) produced by IBS device during oncological high blood loss surgery. An open-label, multicenter clinical study on the removal of EpCAM-positive tumor cells from blood collected during tumor surgery using the Catuvab device is initiated to validate these encouraging results.
\end{abstract}

Keywords: Intraoperative blood salvage, Leukocyte depletion filter, Tumor cell, EpCAM positive tumor, Catumaxomab

\section{Background}

Blood lost during major surgery is conventionally replaced using allogeneic blood transfusion with transfusion rates ranging from 35 to $77 \%[1,2]$. However, perioperative blood transfusion may be associated with

\footnotetext{
*Correspondence: andreas.winter.mail@googlemail.com

1 Department of Anaesthesiology, Intensive Care Medicine and Pain

Therapy, University Hospital Frankfurt, Theodor-Stern-Kai 7,

60590 Frankfurt am Main, Germany

Full list of author information is available at the end of the article
}

increased risks of adverse surgical outcomes including mortality, wound infection, pulmonary and renal complications, sepsis and prolonged hospital stay [3]. Further risks are anaphylaxis, hemolytic reactions, transfusionrelated acute lung injury, and viral infections $[4,5]$. In addition to the potential risks, it should be noted that allogeneic blood has a lower oxygen-carrying capacity than autologous blood [6]. Preliminary data may suggest that allogeneic transfusion may also be an independent risk factor for cancer-specific mortality and overall original author(s) and the source, provide a link to the Creative Commons licence, and indicate if changes were made. The images or other third party material in this article are included in the article's Creative Commons licence, unless indicated otherwise in a credit line to the material. If material is not included in the article's Creative Commons licence and your intended use is not permitted by statutory regulation or exceeds the permitted use, you will need to obtain permission directly from the copyright holder. To view a copy of this licence, visit http://creativecommons.org/licenses/by/4.0/. The Creative Commons Public Domain Dedication waiver (http://creativeco mmons.org/publicdomain/zero/1.0/) applies to the data made available in this article, unless otherwise stated in a credit line to the data. 
mortality in cancer patients [6-8]. One explanation for adverse reactions is a general transient depression of the immune system following transfusion with blood products and transfusion-induced immunomodulation [9-11].

Reinfusion of blood collected in the surgical field, however, is an ancient idea successfully used by John Duncan in 1885 during leg amputation [12]. Some risks and disadvantages of using intraoperative blood salvage [IBS) like hemolysis or salvaged blood syndrome triggering the activation of the coagulation cascade, leading to increased vascular permeability are extremely rare side effects. The risk of disseminated intravascular coagulation due to reinfusion of free hemoglobin, denatured proteins, and micro-aggregates of platelets and leukocytes is regarded theoretical. In contrast to allogeneic red blood cell transfusion, no immunosuppression is expected for IBS treatment [8] resulting in cancer patients' increased chance of relapse free survival and overall survival. IBS has no risk of transmitted disease, such as hepatitis or infection with cytomegalovirus or human immunodeficiency virus, due to test failures and untested unknown viruses. Thus, autologous blood salvage may even contribute to a higher rate of successful cancer treatments [13]. Autologous blood salvage is cost-effective compared to fully burdened allogeneic blood transfusion [3, 14]. The potential risk of infusing malignant cells into patients operated for cancer is the main concern about the safety of IBS. Hence, oncological surgery is still considered a contraindication to IBS in some guidelines $[15,16]$.

An effective and easy-to-implement method for removing tumor cells with metastasizing potential from blood collected during tumor surgery is still needed. A medical device ("Catuvab") based on the selectivity of the monoclonal antibody Catumaxomab has been developed in order to eliminate this potential risk. Catumaxomab is a biologically engineered, intact, trifunctional bispecific anti-EpCAM $\mathrm{x}$ anti-CD3 antibody. EpCAM is a tumor-associated antigen that is overexpressed on most epithelial tumors (carcinomas) and therefore suitable for targeted anti-cancer treatment [17]. The anti-EpCAM binding arm of Catumaxomab [18] has been shown to bind EpCAM-positive tumor cells in vitro with high affinity and specificity [19-21].

The Catuvab procedure consists of Catumaxomab crosslinking EpCAM positive tumor cells with CD3 positive T-cells and Fc-gamma receptor positive immune cells, removal of these cell aggregates during a centrifugation step from EC and final removal of residual tumor cell containing cell aggregates during a final filtration step using a $40 \mu \mathrm{m}$ leukocyte depletion filter (LDF).

This pilot ex-vivo study explored the feasibility, safety aspects and efficacy of Catuvab assessing the number of residual tumor cells, concentration of the pro-inflammatory cytokines IL-6, IL-8 and Catumaxomab antibody amount before, during and at the end of the Catuvab -procedure in the final product, the erythrocyte concentrate (EC) of 16 cancer patients with high probability to be EpCAM positive according to indication.

\section{Methods \\ Patients}

Sixteen consecutive cancer patients undergoing abdominal tumor resection at the University Hospital Frankfurt, Germany, were enrolled in this study (mean 66.8years) between March 2019 and November 2019. Only tumor indications were selected known to be EpCAM-positive such as advanced colon cancer, cholangiocarcinoma, esophageal cancer; ovarian cancer; pancreatic cancer, bile duct cancer, rectum cancer and perihilar cholangiocellular carcinoma.

The clinical study protocol was approved in December 2018 by the Ethics Committee of the University Hospital Frankfurt (number 325/18) and each patient was provided with informed consent. All patients were aware of the procedure and were informed that the shed blood was collected for research purposes and would not be transfused back to them.

\section{Catuvab medical device and Catumaxomab}

Catuvab was used in combination with mechanical auto-transfusion devices, which are part of the operating equipment and remove leukocytes from ECs as standard. The medical device Catuvab kit consists of the following components: Syringe containing $10 \mu \mathrm{g}$ antibody (Catumaxomab) in $100 \mu \mathrm{l}$ buffer (aseptically filled) with cannula, sterilized and sterile packed, Conformité Européenne (CE)-marked; $6 \mathrm{R}$ vial with $5.7 \mathrm{~mL} 0.9 \% \mathrm{NaCl}$ solution (aseptically filled); 2 pieces of $2 \mathrm{~mL}$ syringe with $100 \mu \mathrm{L}$ graduation with cannula $\left(21 \mathrm{G} \times 1 \frac{1 / 2}{2}, 40 \mathrm{~mm}\right)$, sterilized and sterile packed, CE-marked two sterile LDFs, pore size $40 \mu \mathrm{m}$, with silicone hose and standardized connection. The manufacturer of the investigational medical device Catuvab is LINDIS Blood Care GmbH, Neuendorfstr. 20b, Henningsdorf, Germany. Catumaxomab is a biologically engineered, intact, trifunctional bispecific EpCAM x CD3 binding monoclonal antibody consisting of a mouse immunoglobulin G (IgG)2a chain and a rat IgG2b chain $[19,22,23]$.

EpCAM is strongly expressed in squamous cell carcinomas derived from epithelial tissue and can be found in various tumors of epithelial original (gastric carcinoma, ovarian carcinoma, pancreatic carcinoma, colon / rectal carcinoma, non-small cell lung cancer, or peritoneal carcinomatosis) [23-25]. In the past, Catumaxomab has been developed as a targeted therapy 
for intraperitoneal treatment of malignant ascites and epithelial cancers expressing the EpCAM antigen (e.g. bladder, ovarian, pancreatic, lung and gastric cancer). In the lead indication treatment of malignant ascites due to epithelial cancers, the European Medicines Agency (EMA) approved Catumaxomab in 2009. For commercial reasons, the product was withdrawn in 2017.

The primary mode of action of Catumaxomab in the Catuvab device consists of the physical aggregation of tumor cells and lymphocytes/accessory cells and the subsequent removal of the cell aggregates by centrifugation and filtration as part of a machine autotransfusion. Simultaneous binding ex vivo of the antibody to lymphocytes in the patient's intraoperative blood (via the CD3-specific region of the antibody), tumor cells and Fc $\gamma R$-positive accessory immune cells ultimately leads to the formation of larger cell aggregates.

\section{Technical procedure and blood sampling}

Three parameters were investigated in intraoperative blood, during processing and in the final product after filtration with a leukocyte depletion filter (LDF) (Fig. 1):
1) Detection and quantification of EpCAM positive tumor cells in patient blood, the EC and EC after LDF

2) Detection and quantification of cytokines IL-6, IL-8 in the reservoir, in EC and in EC after LDF (probe sampling 1, 2 and 3 )

3) Detection and quantification of Catumaxomab in EC after LDF (probe sampling 3).

Blood and purge solvent accumulated during surgery was collected in a reservoir containing a bone splinter filter (ATR 120 reservoir, Fresenius Kabi, Fig. 1). The blood and purge solvent mixture collected in the reservoir was centrifuged and washed using a IBS machine (C.A.T.S.+, Fresenius Kabi, AT3 Autotransfusionsset, Fresenius Kabi), resulting in an erythrocyte concentrate (EC). The erythrocyte concentrate (EC) was filtered using a $40 \mu \mathrm{m}$ Leukocyte depletion filter (LDF, RS1, Haemonetics) (LDF sample 3). All samples for analysis were extracted via an output connection/an outlet and collected in sterile tubes. The samples collected for antibody analysis were frozen within $1-2 \mathrm{~h}\left(-20^{\circ} \mathrm{C}\right)$. The samples were sent immediately to Trion Research GmbH. The blood samples for cytokine analysis were centrifuged,

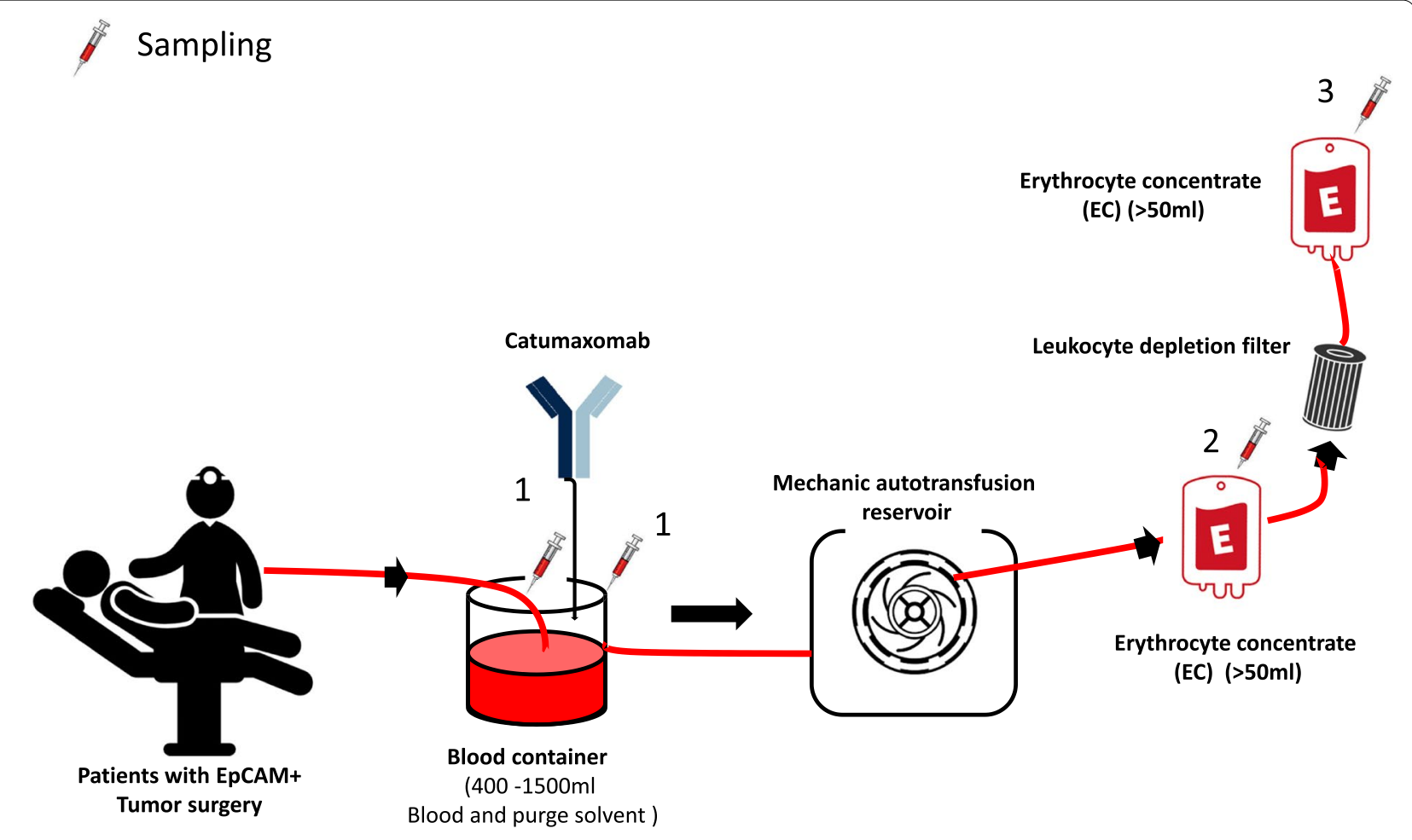

Sampling process: 1: Sampling from blood container without and with Catumaxomab 2: Sampling from EC 3: Sampling from EC after LDF Fig. 1 Sampling procedure of the Catuvab pilot study 
the supernatant (plasma) collected, frozen within 1-2 $\mathrm{h}$ $\left(-20^{\circ} \mathrm{C}\right)$. The samples were sent immediately to the analysis laboratory on dry ice.

Catumaxomab was first diluted and a defined amount of the diluted antibody (2,5 $\mu \mathrm{g}$ or $5 \mu \mathrm{g}$ antibody) was supplied to the blood mixture via a port on the reservoir, using a syringe. Antibodies were distributed within intraoperative blood and aggregates of tumor and immune cells developed within approximately $30 \mathrm{~min}$. During the usual washing and concentration process of the IBS, cell aggregates with a relatively lower density could be separated from the red blood cells in the total mixture by centrifugation. A second filtration step (LDF filter of Catuvab) removed any remaining cell aggregates.

\section{Detection and quantification of EpCAM positive tumor cells, Catumaxomab and IL-6, IL-8}

Detection and quantification of EpCAM positive tumor cells were performed by immunofluorescence staining using the tumor marker EpCAM and cytokeratin. Density gradient centrifugation applying Ficoll-Paque was used as separation medium for lymphocytes and tumor cells that were stained after centrifugation on cytospin preparations. These cytospins were analyzed for the presence of EpCAM-positive tumor cells using the antibody BER-EP4. Quantification of tumor cells was performed by immunofluorescence microscopy with integrated digital image analysis (Applied Imaging) [26].

\section{Detection and quantification of EpCAM binding Catumaxomab in EC before and after LDF}

Catumaxomab concentrations were measured by an established two-site ELISA. Briefly, catumaxomab was captured by an anti-rat IgG light chain-specific antibody (LA1B12, TRION Research, Munich, Germany). Bound catumaxomab was then detected via an anti-mouse.

IgG2a-specific biotin-labeled detection antibody (BD Pharmingen, San Diego, CA). Then, streptavidin-b-galactosidase and its corresponding substrate, chlorphenolred- $\beta$-D-galactopyranosid (Roche Diagnostics, Mannheim, Germany), were added, and the colorimetric reaction was measured at $570 \mathrm{~nm}$. Catumaxomab concentrations were calculated by interpolation on a standard curve. The lower limit of quantification (LLOQ) of the assay was determined to be $125 \mathrm{pg}$ ml-1; the upper limit of quantification was $4000 \mathrm{pg}$ ml-1. All samples were diluted 1:2 before measuring in duplicate $[19,26]$.

\section{Detection and quantification of cytokines IL-6, IL-8 in the reservoir, in EC and in EC after LDF}

As Catumaxomab is well known to activate different types of immune cells, the aim of the measurements was to determine a potential increase of proinflammatory cytokines during the Catuvab procedure [27]. Samples were sent to Synlab MVZ laboratory (Munich, Germany) and cytokines were determined by Luminex ${ }^{\circledR}$ Corporation Multiplex technology using magnetic microsphere beads. The Multiplex ELISA is based on unique fluorescent signature coated microbeads binding specific cytokines which are subsequent measured by laser technology.

\section{Statistics}

Due to the exploratory character and the low number of patients of this pilot study only descriptive statistics using mean values were performed.

\section{Results}

Intraoperative blood volumes

The Catuvab procedure was applied extra-corporally to the intraoperative blood from a total of 16 subjects during surgery. The EC was not re-transfused. For 1 subject (No. 9), obviously no antibody was applied (antibody not detectable for unknown reason in the reservoir), so this subject and related samples were excluded from Catumaxomab antibody amount calculations. The volume of the intraoperative blood mixture (blood and dilution fluid) ranged from $500 \mathrm{ml}$ up to $2800 \mathrm{~mL}$ and the volume of the added dilutive solution during surgery from 0 up to $2500 \mathrm{ml}$. The volume of undiluted intraoperative blood ranged between 300 and $1300 \mathrm{ml}$ for the group of patient samples treated with $2.5 \mu \mathrm{g}$ Catumaxomab to generate tumor cell aggregates. For the group of patient samples treated with $5 \mu \mathrm{g}$, the volume of undiluted (and diluted) intraoperative blood ranged from $300 \mathrm{ml}(1400 \mathrm{ml})$ up to $2550 \mathrm{ml}(2600 \mathrm{ml})$.

\section{Detected tumor cells}

In 10 out of the 16 intraoperative blood samples (Reservoir, EC) (63\%), EpCAM-positive tumor cells were detected in the different Catuvab procedure steps. The number of EpCAM-positive tumor cells ranged from 69 in an EC sample (before filtration (LDF)) to 263,076 in the Reservoir. Finally, no tumor cells were found following the last purification step 3 (leukocytes filtration) in the final EC product (Table 1).

\section{Measured cytokines}

Proinflammatory cytokines (IL-6 and IL-8) were measured in the reservoir before administration of the crosslinking antibody Catumaxomab as well as in the EC before and after filtration (final product) of the 15 antibody receiving subjects. The values for IL- 6 and for IL- 8 (given in bold) in intraoperative blood ranged from below the level of quantification $(B L Q=9.8 \mathrm{pg} / \mathrm{mL} ; 3.1 \mathrm{pg}$ / $\boldsymbol{m L})$ to $2633 \mathrm{pg} / \mathrm{mL}(\mathbf{5 1 8} \mathbf{p g} / \mathbf{m L})$ in the reservoir before 


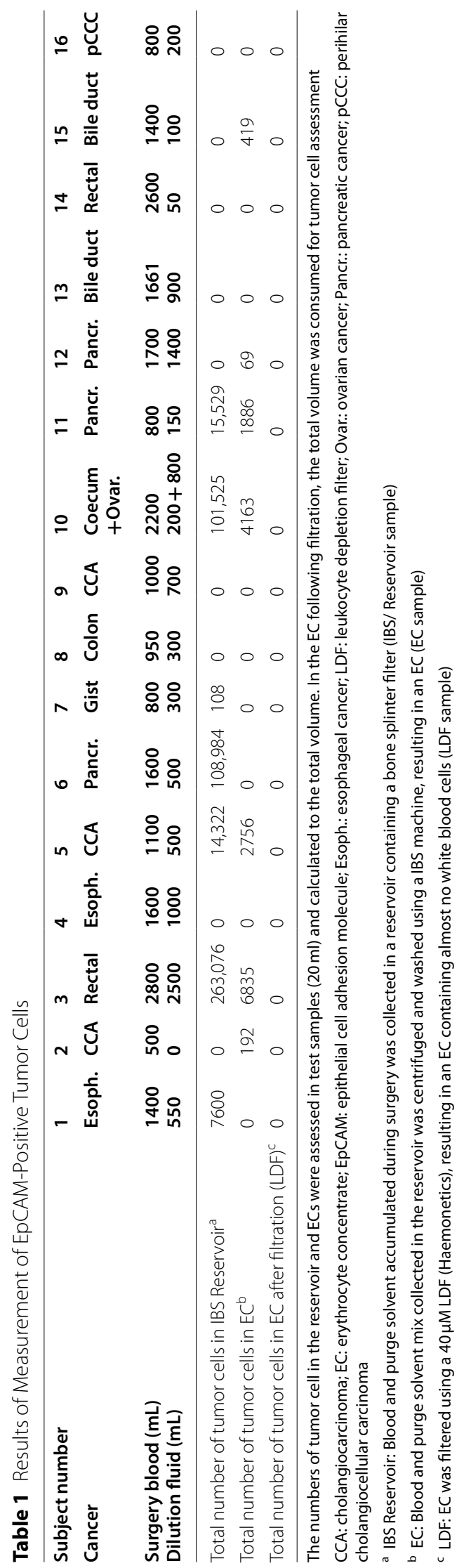




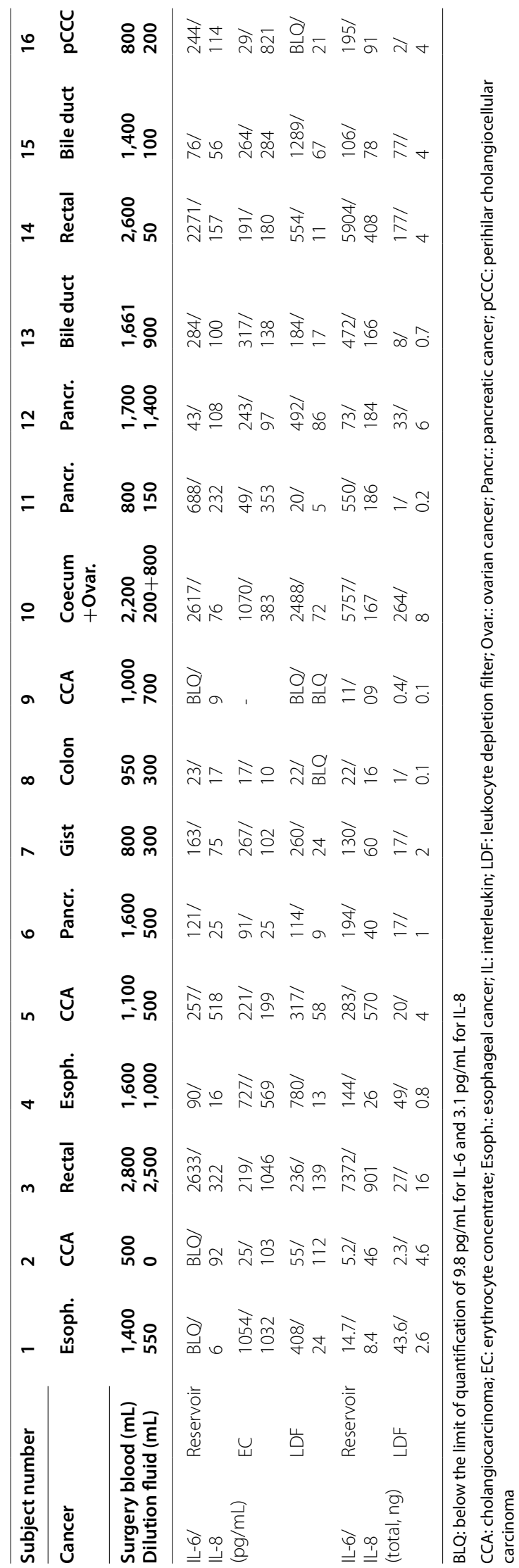


the administration of catumaxomab (mean: $662 \mathrm{pg} / \mathrm{mL}$; $129 \mathrm{pg} / \mathrm{mL}$ ). After administration of catumaxomab, values ranged from 25 to $1070 \mathrm{pg} / \mathrm{mL}$ (10 to $1046 \mathrm{pg} / \mathrm{mL}$ ) (mean: $339 \mathrm{pg} / \mathrm{mL} ; 323 \mathbf{p g} / \mathbf{m L}$ ) in the EC (before filtration). After filtration, the values in the EC ranged from BLQ to $2488 \mathrm{pg} / \mathrm{mL}$ (BLQ to $139 \mathrm{pg} / \mathrm{mL}$ ) (mean: $516 \mathrm{pg} /$ $\mathrm{mL} ; 46 \mathbf{p g} / \mathbf{m L}$ ) (Table 2).

As during the Catuvab-procedure the volumes of intraoperative blood decreased from, e.g., $2800 \mathrm{~mL}$ in the reservoir (mean: $1461 \mathrm{~mL}$ ) to $40 \mathrm{~mL}$ in the EC (mean: $99 \mathrm{~mL}$ ), the total amount of cytokines (IL-6 and IL-8) was also calculated in the reservoir and the EC (after filtration) to assess (i) the reduction in total amount of cytokines during the procedure, and (ii) amount of cytokines that would potentially be reinfused in the patient. The total amount of IL-6 (IL-8 in bold) ranged from $5.2 \mathrm{ng}(\mathbf{8 . 4} \mathbf{n g})$ to $7372 \mathrm{ng}(\mathbf{9 0 1} \mathbf{n g})$ (mean: $1502 \mathrm{ng}$; $204 \mathrm{ng}$ ) in collected intraoperative blood in the reservoir. After completion of the Catuvab procedure, the values of IL-6 (IL-8 in bold) ranged from $1 \mathrm{ng}(0.1 \mathrm{ng})$ to $264 \mathrm{ng}$ (16ng) (mean: 53ng; 3.9 $\mathbf{n g}$ ) in the EC (final product) (Table 2). For the mean values, a 28 -fold (52-fold) reduction was observed in the total amount of cytokines in the final EC when compared to unprocessed collected intraoperative blood in the reservoir.

\section{Residual antibodies}

An important safety aspect of the medical device is the absence of antibody or very low residual antibody in the final product, which is intended to be re-transfused to the subject. During the exploratory pilot study, different ways to apply the antibody were tested. For the first 10 subjects, the way of antibody application was not clearly defined, and in some cases the antibody was applied first in the reservoir before the collection of intraoperative blood was started. This was the case for Subjects 2 and 7, who exhibited a relatively high concentration of antibody $(1694 \mathrm{pg} / \mathrm{mL}$ and $1026 \mathrm{pg} / \mathrm{mL}$, respectively) following the application of $2.5 \mu \mathrm{g}$ antibody (Table 3 ). To improve the procedure, in the next 5 subjects (No. 11-16), the antibody was applied only after a minimum of $350 \mathrm{~mL}$ intraoperative blood volume was collected in the reservoir, enabling an improved interaction and binding of the antibody with immune cells and EpCAM- positive tumor cells. This change in the experimental setting probably resulted in a decreased antibody concentration below the limit of quantification (BLQ) in Subjects 11 and 16, and to $160 \mathrm{pg} / \mathrm{mL}$ in Subject 15 (Table 3). Blood volumes exceeding $>1500 \mathrm{~mL}$ were collected from patient 12 and 13 and further $2.5 \mu \mathrm{g}$ antibody was applied to the reservoir. This resulted in higher concentrations of antibody in the EC $(888 \mathrm{pg} / \mathrm{mL}$ and $628 \mathrm{pg} / \mathrm{mL}$, respectively). These results suggested to limit intraoperative blood volume to
$1500 \mathrm{~mL}$ per IBS cycle (a second cycle could be started if the total amount of intraoperative blood was $\geq 1500 \mathrm{~mL}$ ). After establishment of both improvements regarding antibody application in the reservoir starting from patient 14-16, the total amounts of antibody found in the final EC ranged from BLQ $(\leq 125 \mathrm{pg} / \mathrm{mL})$ up to $9 \mathrm{ng}$ (Table 3).

For the upcoming multicenter REMOVE study with the reinfusion of Catuvab- treated EC the antibody will be added after a minimum $(400 \mathrm{~mL})$ intraoperative blood collection and instituting a maximum of $1500 \mathrm{~mL}$ intraoperative blood per IBS cycle.

\section{Discussion}

The spreading of tumor cells during surgery can originate from tumor cells left at the resection line, inadvertent rupture of the tumor, prior presence of tumor cells in the peritoneal cavity, or intraoperative release into the blood by pressurization, but unlikely from circulating tumor cells $[28,29]$. Several studies have demonstrated that tumor cells are commonly detected in red cell concentrates in autologous reinfusion bags in $62-90 \%$ of cases and these cells demonstrate proliferation capacity, invasiveness, and tumorigenicity $[28,30,31]$. Hansen et al. [28] suggested that tumor cells identified from surgical fields are different from those circulating in the peripheral blood, as both the detection frequency and number of tumor cells are much higher in surgical fields than those in the circulation at the end of surgery. It was also found that an IBS itself was not sufficient for removing tumor cells in most cases [30].

To handle this problem, leukocyte depletion filters (LDFs) have been tested in spine-cancer patients and in a variety of urologic malignancies, including prostate, urothelial, renal and liver cancer [32-35].

Kumar et al. [36] showed that IBS using LDFs can effectively eliminate tumor cells from salvaged blood in spinal tumor surgery in 8 of 11 tested subjects. The mechanisms for the entrapment of tumor cells by LDF is likely a combination of mechanical sieving and unspecific biological adhesion processes [37]. However, whether tumor cells are completely filtered in clinical settings and whether LDFs eliminate the risk of tumor cell metastasis, remains unknown. Thus, regulatory guidelines e.g. in Germany (Querschnittsleitlinie der Bundesärztekammer 2020, www.baek.de) prohibit the retransfusion of autologous ECs from intraoperative blood gained during cancer surgery.

Wu et al. [38] conducted a meta-analysis to evaluate the oncological safety of pure IBS versus allogeneic blood transfusion in surgery of malignant disease. IBS with LDF was reported to be comparable to allogeneic blood regarding tumor recurrence rate, regardless of the 


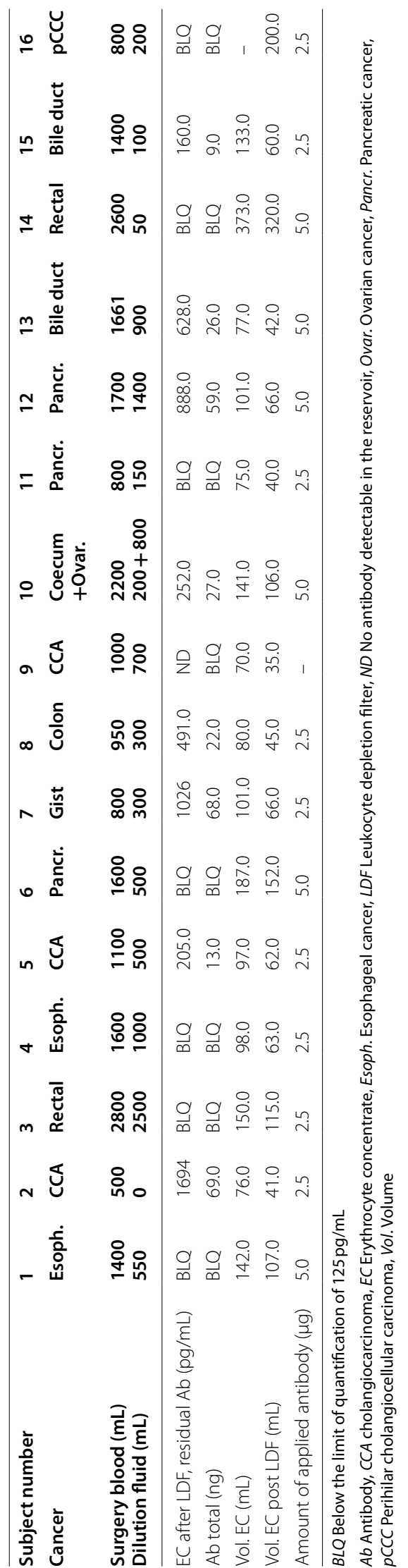


effect-cost ratio or the efficacy in tumor surgery. However, published data suggest that the capability of an LDF to filter tumor cells is load limited. Thus, when the number of tumor cells is too high $\left(\geq 2 \times 10^{3}\right)$, the filter will fail to remove tumor cells completely, so that the risk of distant spread of the tumor still remains [31,37,39].

As an alternative, the irradiation of blood prior to its reinfusion has also been proposed. Blood irradiation ensures a 10 to $12 \mathrm{log}$ reduction in the number of tumor cells, which is considered sufficient to eliminate all tumor cells without impairing the function of red blood cells [31]. Besides that, irradiation also damages the DNA of malignant cells, reducing their multiplication capacity. Irradiation treatments require special large-scale radiation equipment as well as strict radiation protection management. Most of medical institutions worldwide do not have such conditions, and irradiation treatment cannot usually be completed in the operating room, which reasonably limits its wide clinical implementation.

An effective and easy-to-implement method for removing EpCAM positive tumor cells with metastasizing potential $[40,41]$ from blood collected during tumor surgery was invented based on the selectivity of the monoclonal anti-EpCAM antibody Catumaxomab. EpCAM is expressed by a broad spectrum of epithelial solid cancer types in the range of $>90 \%$ (as e.g. ovarian-, gastric-, colonic-, pancreas-, bladder-, prostate-, endometrial- and non- small cell lung cancer) $[24,25]$ and Catumaxomab is able to bind even at a very low EpCAM expression levels due to its high affinity and cell binding potential [20] making Catuvab applicable for a broad spectrum of solid cancer surgeries.

Here, we have to discuss the role of EpCAM negative tumor cells, which could potentially escape the Catuvab procedure. In this context, three conditions have to be considered. Firstly, only cancer indications which express EpCAM in $>90 \%$ of cases should be considered. Secondly, also EpCAM negative tumor cells will be reduced up to $90 \%$ due to centrifugation and filtration steps independent of the binding and crosslinking ability of the trifunctional antibody (filter characteristics). Thirdly, several publications have demonstrated a higher metastasizing potential for EpCAM positive carcinoma cells compared to EpCAM negative tumor cells [40, 41]. Taken together, it seems that the risk /benefit ratio using Catu$v a b$ regarding the potential contamination with residual EpCAM negative tumor cells might be acceptable, but needs further clinical evaluation.

This pilot study showed that it is feasible to implement Catuvab procedure easily in the blood collection procedure. Even at a high tumor cell level in intraoperative blood (e.g. $>2.6 \times 10^{5}$ ) it was possible to eliminate these cells after the final LDF filtration step. IL-6 and IL-8 amounts could be markedly reduced in mean 28 -fold and 52-fold respectively indicating cytokinewash out effects of the procedure. The mean values of the total amount of IL- 6 and IL- 8 in the final product are considered uncritical given the approximately 2000to 3000 -fold dilution in the subject's body. This interpretation is based on the calculation that patients body blood volume ranges in average between 5 and 71 containing about $2-31$ of plasma. Even the measured peak value of $264 \mathrm{ng}$ of IL-6 would not lead to critical values in this scenario. Thus, safety aspects regarding proinflammatory cytokines should not be an issue for the Catuvab procedure.

Residual Catumaxomab antibody was detected in 8 of 16 of the final EC products at a decreased amount (37 ng in mean) which is considered non-critical regarding the $\mathrm{LD}_{50}>5.0 \mathrm{mg} / \mathrm{kg}$ in mice [42], no toxicity signs up to and $300 \mu \mathrm{g} / \mathrm{kg}$ in cynomolgus monkeys [43], the MTD of $7 \mu \mathrm{g}$ confirmed in clinical trial [44] exceeding the residual drug in the EC by magnitudes of order as well as the general clinical experience [26].

\section{Conclusion}

As auto-transfusion devices itself are not sufficient for removing tumor cells $[28,29]$ and additional measures such as the application of LDF markedly reduced the risk for reintroduction of tumor cells, but failed in the presence of a high tumor load in salvaged blood [37], a residual risk of contamination remains. Despite to the low number of patients, the results of this ex vivo study indicate a complete removal of EpCAM positive tumor cells, which has to be validated in a clinical study. The primary objective of this upcoming REMOVE study is to demonstrate that the Catuvab device utilized during IBS procedures (including centrifugation step and leukocyte depletion filter) depletes EpCAM-positive tumor cells effectively in autologous blood retransfusion.

\section{Abbreviations}

Ab: Antibody; BLQ: Below the limit of quantification; CCA: Cholangiocarcinoma; EC: Erythrocyte concentrate; EpCAM: Epithelial cell adhesion molecule; Esoph: Esophageal cancer; IBS: Intraoperative blood salvage; IL: Interleukin; LDF: Leukocyte depletion filter; ND: No antibody detectable in the reservoir; Ovar: Ovarian cancer;"; Pancr: Pancreatic cancer;; pCCC: Perihilar cholangiocelIular carcinoma; Vol: Volume.

\section{Authors' contributions}

All authors have read and approved the manuscript. A.W.: Data collection, data analysis and manuscript writing. P.M.: Project development, data collection and created Fig. 1, A.S., P.R., C.K.: Project development, data collection. H.L.: Project development, data collection and created Table 1, 2 and 3. K.Z.: Project development, read and approved the final manuscript. 


\section{Funding}

The study was funded by LINDIS Blood Care GmbH, Neuendorfstr. 20b, Henningsdorf, Germany. Open Access funding enabled and organized by Projekt DEAL.

\section{Availability of data and materials}

The datasets analysed are available from the corresponding author upon reasonable request.

For data request please contact Andreas Winter, University Hospital Frankfurt, Germany (andreas.winter@kgu.de).

\section{Declarations}

\section{Ethics approval and consent to participate}

All procedures performed in studies involving human participants were in accordance with the ethical standards with the 1964 Helsinki Declaration and its later amendments or comparable ethical.

standards. Informed consent was obtained from all participants and was written in this study.

\section{Consent for publication}

Not applicable.

\section{Competing interests}

Horst Lindhofer: shares in or honoraria from the company making the medical device.

Andreas Winter, Andreas Schnitzbauer: no competing interests declared. Peter Ruf, Claudia Kellermann, Horst Lindhofer: Employees of Trion Research GmbH, Am Klopferspitz 19, 82152 Martinsried, Germany.

Patrick Meybohm, Kai Zacharowski: received grants by B. Braun Melsungen, CSL Behring, Fresenius Kabi and Vifor Pharma for the implementation of Frankfurt's Patient Blood Management Program; by Pfizer, Haemonetics, and Dr. F. Köhler Chemie GmbH for investigator-initiated trial.

\section{Author details}

${ }^{1}$ Department of Anaesthesiology, Intensive Care Medicine and Pain Therapy, University Hospital Frankfurt, Theodor-Stern-Kai 7, 60590 Frankfurt am Main, Germany. ${ }^{2}$ Department of Anaesthesiology, University Hospital Wuerzburg, Oberdürrbacher Straße 6, 97080 Wuerzburg, Germany. ${ }^{3}$ Department of General and Visceral Surgery, University Hospital Frankfurt, Theodor-Stern-Kai 7, 60590 Frankfurt am Main, Germany. ${ }^{4}$ Trion Research GmbH, Am Klopferspitz 19, 82152 Martinsried, Germany.

Received: 24 February 2021 Accepted: 13 October 2021

Published online: 29 October 2021

\section{References}

1. Prescott LS, Aloia TA, Brown AJ, et al. Perioperative blood transfusion in gynecologic oncology surgery: analysis of the National Surgical Quality Improvement Program Database. Gynecol Oncol. 2015;136:65-70.

2. Warner LL, Dowdy SC, Martin JR, et al. The impact of perioperative packed red blood cell transfusion on survival in epithelial ovarian cancer. Int J Gynecol Cancer. 2013;23:1612-9.

3. Ferraris VA, Davenport DL, Saha SP, et al. Surgical outcomes and transfusion of minimal amounts of blood in the operating room. Arch Surg. 2012;147:49-55.

4. Holt S, Donaldson H, Hazlehurst G, Varghese Z, et al. Acute transplant rejection induced by blood transfusion reaction to the Kidd blood group system. Nephrol Dial Transplant. 2004;19:2403-6. https://doi.org/10.1093/ ndt/gfh333 PMID: 15299103.

5. Lenhard V, Hansen B, Roelcke D, et al. Influence of Lewis and other blood group systems in kidney transplantation. Proc Eur Dial Transplant Assoc. 1983;19:432-7 PMID:6348744.

6. Linder BJ, Thompson $\mathrm{RH}$, Leibovich $\mathrm{BC}$, et al. The impact of perioperative blood transfusion on survival after nephrectomy for non-metastatic renal cell carcinoma (RCC). Brit J Urol Int. 2014;114:368-74. 24471825. https:// doi.org/10.1111/bju.12535.
7. Soubra A, Zabell JR, Adejoro O, Konety BR. Effect of perioperative blood transfusion on mortality for major urologic malignancies. Clin Genitourin Cancer. 2015;13:e173-81. PMID: 25600760. https://doi.org/10.1016/j.clgc. 2014.12.006.

8. Linder BJ, Frank I, Cheville JC, et al. The impact of perioperative blood transfusion on cancer recurrence and survival following radical cystectomy. Eur Urol. 2013;63:839-45. PMID: 23332883. https://doi.org/10. 1016/j.eururo.2013.01.004.

9. Thomas D, Bolton-Maggs P, Cohen $\mathrm{H}$ et al. The 16th Annual SHOT Report. [https://www.shotuk.org/wp-content/uploads/myimages/ summary-2012.pdf] (Accessed 5 Aug 2020).

10. Blajchman MA, Vamvakas EC. Transfusion-related immunomodulation. Blood Rev. 2007;21(6):327-48.

11. Goubran H, Sheridan D, Radosevic J, et al. Transfusion-related immunomodulation and cancer. Transfus Apher Sci. 2017;56:336-40.

12. Duncan J. On re-infusion of blood in primary and other amputations. Br Med J. 1886;1:192-3.

13. Wu HL, Tai YH, Lin SP. The impact of blood transfusion on recurrence and mortality following colorectal cancer resection: a propensity score analysis of 4,030 patients. Sci Rep. 2018;8(1):13345.

14. Shander A, Hofmann A, Gombotz H, et al. Estimating the cost of blood: past, present, and future directions. Best Pract Res Clin Anaesthesiol. 2007;21(2):271-89.

15. Association of Anaesthetists guidelines: cell salvage for peri-operative blood conservation 2018. https://www.thieme-connect.com/produ cts/ejournals/pdf/10.1055/a-0593-4377.pdf (Accessed 1 Aug 2020).

16. Richtlinie zur Gewinnung von Blut und Blutbestandteilen und zur Anwendung von Blutprodukten (Richtlinie Hämotherapie) Bundesärztekammer Gesamtnovelle 2017, https://www.bundesaerztekammer. de/fileadmin/user_upload/downloads/pdf-Ordner/MuE/Richtlinie_ Haemotherapie E A 2019.pdf] (Accessed 5 Aug 2020).

17. Balzar M, Winter M, de Boer C, Litvinov S. The biology of the 17-1A antigen (Ep-CAM). J Mole Med. 1999;77(10):699-712.

18. Ruf $P$, Gires $O$, Jäger M, Fellinger $K, A t z ~ J$, Lindhofer $H$. Characterisation of the new EpCAM-specific antibody HO-3: implications for trifunctional antibody immunotherapy of cancer. Br J Cancer. 2007;97(3):315-21.

19. Ruf $P$, Kluge $M$, Jäger $M$, Burges $A$, et al. Pharmacokinetics, immunogenicity and bioactivity of the therapeutic antibody catumaxomab intraperitoneally administered to cancer patients. Bri J Cli Pharmacol. 2007;69(6):617-625 2010.

20. Andree KC, Barradas AMC, Nguyen AT. Capture of tumore cells on antiEpCAM-functionalized poly (acrylic acid)-coated surfaces. ACS Appl Mater Interfaces. 2016;8(23):14349-56.

21. Pavšič M, Gunčar G, Djinović-Carugo K, et al. Crystal structure and its bearing towards an understanding of key biological functions of EpCAM. Nat Commun. 2014;5:4764

22. Riesenberg R, Buchner A, Pohla H, Lindhofer $\mathrm{H}$. Lysis of prostate carcinoma cells by trifunctional bi-specific antibodies (alpha EpCAM $x$ alpha CD3). J Histochem Cytochem. 2001;49(7):911-7.

23. Schmitt M, Schmitt A, Reinhardt $P$, et al. Opsonization with a trifunctional bispecific (aCD3 $\times$ aEpCAM) antibody results in efficient lysis in vitro and in vivo of EpCAM positive tumor cells by cytotoxic $T$ lymphocytes. Int J Oncol. 2004;25(4):841-8.

24. Spizzo G, Fong D, Wurm M, Ensinger C, Obrist $P$, et al. EpCAM expression in primary tumour tissues andmetastases: an immunohistochemical analysis. J Clin Pathol. 2011;64:41.

25. Keller L, Werner S, Pantel K. Biology and clinical relevance of EpCAM. Cell Stress. 2019;3(6):165-80.

26. Jager $M$, Schoberth $A$, Ruf $P$, Hess J, et al. Immunomonitoring results of a phase II/III study of malignant ascites patients treated with the trifunctional antibody catumaxomab (anti-EpCAM $x$ anti-CD3). Cancer Res. 2012;72(1):24-32.

27. Zeidler R, Reisbach G, Wollenberg B, et al. Simultaneous activation of T-cells and accessory cells by a new class of intact bi- specific antibody results in efficient tumor cell killing. J Immunol. 1999;163(3):1246-52.

28. Hansen E, Futamura N, Nakanishi $\mathrm{H}$, Hirose $\mathrm{H}$, et al. The effect of storage on the survival of cancer cells in blood and efficient elimination of contaminating cancer cells by a leukocyte depletion filter. Am J Surg. 2005;71:585. 
29. Dale RF, Kipling RM, Smith MF, et al. Separation of malignant cells during autotransfusion. Bri J Surg. 1988;75(581):10.

30. Hansen E, Wolff N, Knuechel R, et al. Tumor cells in blood shed from the surgical field. Arch Surg. 1995;130:387.

31. Zhang FJ, Yang JT, Tang LH, Wang WN, Sun K, Ming Y, et al. Effect of X-ray irradiation on hepatocarcinoma cells and erythrocytes in salvaged blood. Sci Rep. 2020;7:7995. https://doi.org/10.1038/s41598-017-08405-z.

32. Ciepluch B, Wilson-Robles $H$, Levine $G$, et al. Removal of hemangiosarcoma cells from canine blood with a cell salvage system and leukocyte reduction filter. Vet Surg. 2018;47(2):293-30.

33. Kumar N, Zaw AS, Koo BL, Nandi S, et al. Intraoperative cell salvage in metastatic spine tumour surgery reduces potential for reinfusion of viable cancer cells. Eur Spine J. 2016;25:4008-15.

34. Ferroni MF, Correa AF, Timothy D, Lyon TD, Benjamin J, Davies BJ, et al. The use of intraoperative cell salvage in urologic oncology. Rev Urol. 2017;19(2):89-96.

35. Pinto AM, Chedid MF, Capra RP, Prediger C, et al. Intraoperative cell salvage with autologous transfusion in liver transplantation. World $]$ Gastrointest Surg. 2019;1 1(1):11-8. https://doi.org/10.4240/wjgs.v11.11.11.

36. Kumar N, Ahmed Q, Lee VK, et al. Can there be a place for intraoperative salvaged blood in spine tumor surgery? Ann Surg Oncol. 2014;21(7):2436-43.

37. Gwak MS, Lee KW, Kim SY, et al. Can a leukocyte depletion filter (LDF) reduce the risk of reintroduction of hepatocellular carcinoma cells? Liver Transpl. 2005;11:331.

38. Wu W, Zhang W, Zhang W, et al. Survival analysis of intraoperative blood salvage for patients with malignancy disease: a
PRISMA-compliant systematic review and meta-analysis. Medicine (Baltimore). 2019;98(27):e16040.

39. Hansen E. Failed evidence of tumour cell removal from salvaged blood after leucocyte depletion. Transfus Med. 2006;16(3):213-6.

40. de Wit S, van Dalum G, Lenferink ATM, et al. The detection of EpCAM+ and EpCAM- circulating tumor cells. Sci Rep. 2015;5:122-7.

41. Liu X, Li J, Cadilha L, Markota A, et al. Epithelial-type systemic breast carcinoma cells with a restricted mesenchymal transition are a major source of metastasis. Sci Adv. 2019;5:eaav4275.

42. Schwaiger FW. Acute intravenous toxicity study of REMOVAB (anti-EpCAM $x$ anti-CD3) in the mouse (report nr 075.002.315), Aurigon Life Science; 2003.

43. Leuschner J. REMOVAB- dose escalation study with 6 single doses after intravenous 2-hour infusion in the cynolmolgus monkey (report nr. 14348/01) LPT laboratory of. Pharmacol Toxicol. 2001;2:2-5.

44. Mau-Sorensen M, Dittrich C, Dienstmann R, et al. A phase I trial of intravenous catumaxomab: a bispecific monoclonal antibody targeting EpCAM and the T cell coreceptor CD3. Cancer Chemother Pharmacol. 2015;75(5):1065-73.

\section{Publisher's Note}

Springer Nature remains neutral with regard to jurisdictional claims in published maps and institutional affiliations.
Ready to submit your research? Choose BMC and benefit from:

- fast, convenient online submission

- thorough peer review by experienced researchers in your field

- rapid publication on acceptance

- support for research data, including large and complex data types

- gold Open Access which fosters wider collaboration and increased citations

- maximum visibility for your research: over 100M website views per year

At BMC, research is always in progress.

Learn more biomedcentral.com/submissions 